\title{
NEVER ENDING SYMPTOMS IN 2 SIBLINGS
}

\section{Adriana Šufliarska ${ }^{1}$, Bronislava Kundrátová ${ }^{2}$, L'ubica Kövérová ${ }^{2}$}

${ }^{1}$ PEDIAMED Ltd. Pediatric Primary Care, ${ }^{2}$ Research Institute for Child Psychology (VÚDPaP), Bratislava Slovakia

Background and aims: In an outpatient setting we have often registered parents repeatedly seeing a paediatrician with their child because of symptoms which were reported to be very serious by the parent however with almost negative results found by the physician. Therefore, many examinations have been performed on these children to rule out the presence of any disease.

Methods: The authors present a case report of 2 sisters with an age difference of 4 years. The number of visits at doctors' offices and the main problems are summarised in the tables.

Family history: Mother of the children suffers from Coeliac disease, Allergy to caw milk protein, Lactose intolerance. Her mother from Breast cancer, Chronic pancreatitis. The parents of the children are divorced, the children live with their mother.

\begin{tabular}{|c|c|c|c|}
\hline \multicolumn{3}{|c|}{ Child No 1: numbers of visits at doctors' offices and } \\
the main problems \\
\hline Age & $\begin{array}{c}\text { Number } \\
\text { of visits }\end{array}$ & Sent to specialist & Problems \\
\hline 2 & 13 & $\begin{array}{c}\text { Immunology, } \\
\text { Dermatology }\end{array}$ & $\begin{array}{c}\text { Upper respiratory } \\
\text { tract infection, } \\
\text { Diarrhea, Rash }\end{array}$ \\
\hline 3 & 6 & $\begin{array}{c}\text { Immunology } \\
\text { Dermatology } \\
\text { Pneumology }\end{array}$ & $\begin{array}{c}\text { Upper respiratory } \\
\text { tract infection Rash }\end{array}$ \\
\hline 4 & 6 & $\begin{array}{c}\text { Orthopaedics } \\
\text { Otorhinolaryngology }\end{array}$ & $\begin{array}{c}\text { Ear pain, Incorrect } \\
\text { walking }\end{array}$ \\
\hline 5 & 12 & $\begin{array}{c}\text { Neurology } \\
\text { Ophthalmology } \\
\text { Gastroenterology } \\
\text { Psychology }\end{array}$ & $\begin{array}{c}\text { Upper respiratory } \\
\text { tract infection, } \\
\text { Abdominal pain, } \\
\text { Seizures, Falls, }\end{array}$ \\
\hline 6 & 10 & $\begin{array}{c}\text { Upper respiratory } \\
\text { tract infection }\end{array}$ \\
\hline 7 & 13 & $\begin{array}{c}\text { Upper respiratory } \\
\text { tract infection }\end{array}$ \\
\hline 8 & 9 & $\begin{array}{c}\text { Upper respiratory } \\
\text { tract infection } \\
\text { Cardiology } \\
\text { Abdominal pain }\end{array}$ \\
\hline
\end{tabular}

\begin{tabular}{|c|c|c|c|}
\hline \multicolumn{3}{|c|}{ Child No 2: numbers of visits at doctors' offices and the main } \\
problems
\end{tabular}

The older child was hospitalised at the age of 10 years. Laboratory tests, Abdominal ultrasound, gastrofibroscopy with endoscopy, MRI of the head were performed. No medical condition that could explain the reported problems was found. The younger was hospitalised at the age of 8 years, gastrofibroscopy, with endoscopy was performed. HP mild positivity was found. No signs of myopathy were confirmedd. She is has been still complaining of cramps in her legs.

Diagnosis: Münchhausen syndrome by proxy was suggested after answering the following diagnostic questions:

Were the results of the examinations in accordance with the symptoms described by the mother? No.

Was the mother satisfied with the negative result of the investigations? No.

Were the symptoms also seen by health care provider? No.

Where the tests performed on behalf of the history described by the mother? Yes

Conclusions: In an outpatient setting it seems to be difficult to find out whether the symptoms of a disease are real, especially in small children. We should be very cautious when parents are coming very often to the doctor with new signs and symptoms and are not satisfied with negative results. 